\title{
Estimation of the biomass stock of trees in Sweden: comparison of biomass equations and age-dependent biomass expansion factors
}

\author{
Anneli JALKANEN ${ }^{\mathrm{a}}$, Raisa MÄKIPÄ̈̈ ${ }^{\mathrm{b}} *$ Göran STÅHL $^{\mathrm{c}}$, Aleksi LEHTONEN ${ }^{\mathrm{b}}$, Hans PETERSSON ${ }^{\mathrm{c}}$ \\ a University of Helsinki, PO Box 27, 00014 University of Helsinki, Finland \\ b Finnish Forest Research Institute, Unioninkatu 40 A, 00170 Helsinki, Finland \\ ${ }^{c}$ Swedish University of Agricultural Sciences, Forest Resource Management and Geomatics, 90183 Umeå, Sweden
}

(Received 13 April 2004; accepted 14 March 2005)

\begin{abstract}
Differences and uncertainties of alternative methods applicable to estimation of biomass in national greenhouse gas inventories are evaluated. The alternative methods employed to obtain biomass estimates of trees are (1) aggregated stand-level volume estimates multiplied by biomass expansion factors (BEF), and (2) biomass equations applied to tree-wise data of a national forest inventory. In comparison to the reference value obtained using tree-wise biomass equations, the age-dependent BEFs for the whole of Sweden resulted in a $6.7 \%$ lower aboveground biomass estimate. The estimates were the closest for conifer-dominated forests in central Sweden, and the largest discrepancies were for spruce in southern Sweden. This result indicates that these age-dependent BEFs cannot be applied to conditions where stand development deviates from the conditions under which the BEFs were developed. The degree of uncertainty in both methods was highest in the young age-classes. At the regional level, the relative standard errors of the BEF-based biomass estimates were in the range of 4-13\%.
\end{abstract}

biomass function / carbon stock of trees / forest inventory / greenhouse gas inventory / uncertainty

Résumé - Estimation de la biomasse sur pied en Suède : comparaison des équations de biomasses avec les facteurs d'expansion de la biomasse (BEF) liés à l'âge. Nous avons évalué les différences et les incertitudes des méthodes alternatives d'estimation utilisable dans les inventaires nationaux de GES. Ces méthodes sont (1) la multiplication des estimations du volume au niveau des peuplements avec les facteurs d'expansion de la biomasse (BEF) et (2) l'application des équations de biomasses sur les données par arbres de l'IFN. La méthode des BEF a donné, pour la forêt suédoise, une estimation de la biomasse inférieure de 6,7\% par rapport à la méthode de référence (2). Les différences entre estimations étaient minimales dans les forêts de conifères du centre du pays et maximales dans les forêts d'épicéas du sud. Cela indiquerait que les BEF liés à l'âge ne sont pas applicables dans des conditions s'éloignant du développement des peuplements boréaux. Le degré d'incertitude était le plus élevé pour les classes d'âge jeunes. Au niveau régional, l'erreur relative standard des estimations se basant sur les BEF se situait entre 4 et $13 \%$.

équation de biomasses / stock de carbone sur pied / inventaire forestier / inventaire des gaz à effet de serre / degré d'incertitude

\section{INTRODUCTION}

Estimation of the biomass and carbon stock of trees has gained importance as a result of the Climate Convention and the Kyoto Protocol. Extraction and storage of excess carbon from the atmosphere into the forests is being considered as one of the mechanisms for mitigation of climate change. Currently, the methods used for calculating the biomass and carbon stock of trees are imprecise and, in general, they lack estimation of the degree of uncertainty as suggested by the Intergovernmental Panel on Climate Change (IPCC) good practice guidance [5]. Information on the major uncertainties involved in the calculations of forest carbon sinks is needed in the negotiations of the Climate Convention. Furthermore, analysis of the sources of error and identification of the key sources as well as quantification of the overall level of uncertainty of forest car- bon inventories will aid in prioritizing efforts to develop the inventories.

In general, estimates of forest carbon stock and stock changes are obtained by calculations based of growing stock and net increment with the aid of simple conversion factors [7, $8,12,20,21]$. Quantitative uncertainty estimates (in terms of relative standard error [RSE]) of the volume of growing stock are provided by the national forest inventories (NFIs), and the sampling errors reported are known to be less than $1 \%$ in several European countries [10]. In addition to this sampling error, calculation of the biomass stock of trees by applying volume equations and BEFs introduces additional sources of error to the overall uncertainty of biomass estimates. In general, model errors involved in the forest inventories are not accounted for and quantitative uncertainties of the applied conversion and

\footnotetext{
* Corresponding author: Raisa.Makipaa@metla.fi
} 
expansion factors are not known or are assumed to be large [5]. Conversion from stem volumes into whole-tree biomass is one of the notable sources of error in forest carbon inventories [18]. Since most of the currently applied BEFs are not based on regionally representative biomass sampling, they are likely to give biased biomass estimates as a result.

Attempts have already been made to quantify and reduce the uncertainties involved in BEFs by developing uncertainty estimation and by taking into account the variation in the allometry of trees. Since allometry varies according to size of the trees, the variation in the BEFs can be related to dimensions of single trees, or stand-level parameters such as dimensions of the median tree of a stand, merchantable stem volume or stand age $[2,6,11,19]$. These BEFs should result in more accurate biomass estimates than constant BEFs, since they account for variation in the allometry of trees according to stand development. Moreover, age-dependent BEFs are able to take into account changes in the age-class distributions of growing stock. The effect of average forest age structure on productivity at the national level was also studied by Milne and Van Oijen [15]. Regional biomass estimates can also be calculated by applying biomass equations $[13,14,23]$ when treewise data of forest inventories are available. This approach should provide accurate estimates of the biomass of trees as far as the biomass equations are based on regionally representative sampling.

A high degree of inconsistency in carbon stock inventories both in methods and in applied conversion factors across countries is often observed (e.g. $[12,21])$. According to the IPCC good practice guidance, use of simple conversion factors is recommended for Tier 1 inventories (Tier 1 indicates the lowest level of reliability and data needs of inventory) [5]. In the higher tiers, more specific BEFs and allometric equations should be used. However, differences in biomass and carbon estimates and their uncertainties resulting from the use of different methods are very rarely evaluated, with few exceptions like Van Camp et al. [22].

In the present study, we evaluated differences in the biomass estimates and their uncertainties resulting from the use of various methods applied to forest biomass and carbon stock assessments at the regional and national levels. The objective was to compare three methods applicable for estimating regional and national biomass stocks of trees. Biomass stock was calculated (1) with the aid of currently applied constant biomass expansion factors (BEFs), (2) by applying age-dependent BEFs developed for boreal forests in Finland [11] and (3) with biomass equations [14] applied directly to treewise data of Swedish NFI sample plots. The first two methods convert the stem volume estimates to biomass, and the third method is based on the aggregation of tree biomasses that are estimated from the tree-wise dimensions measured in the NFI sample plots.

\section{MATERIALS AND METHODS}

\subsection{Data from the Swedish National Forest Inventory}

Data from the Swedish NFI (1997-2001), with the Swedish definition for forest land, were used in the calculations of this study [17]. The data were divided between four regions: Norra Norrland, Södra Norrland, Svealand and Götaland (Fig. 1). The climatic conditions as well as the average stem volume and species composition of forests

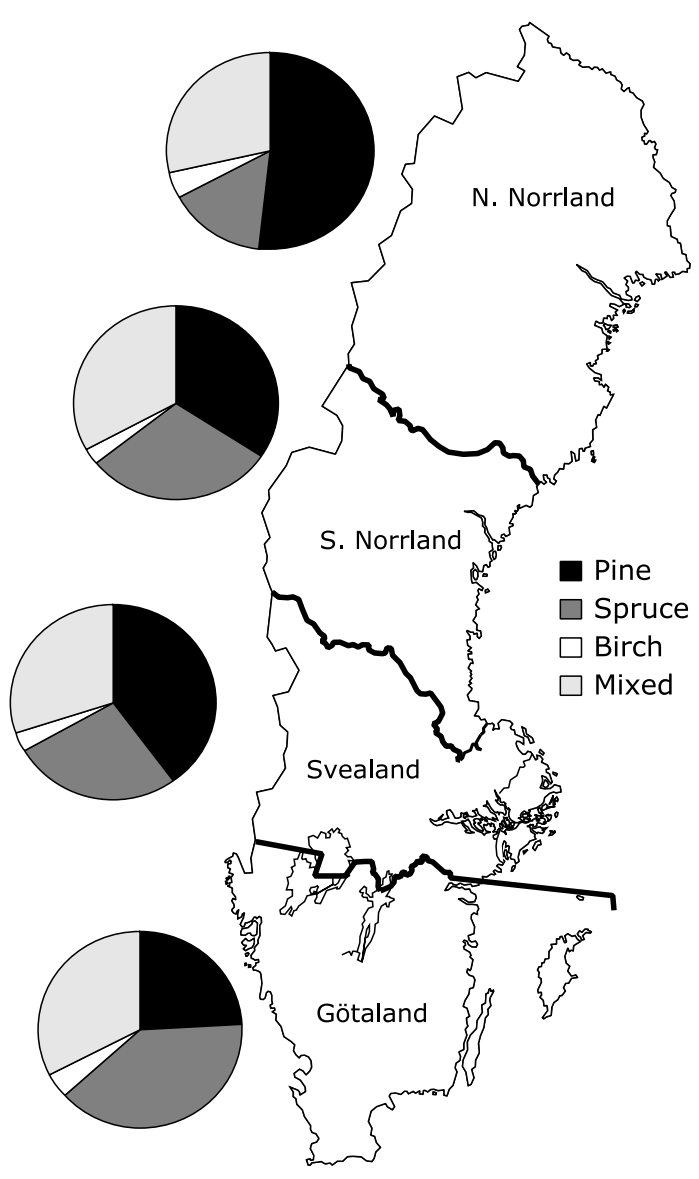

Figure1. Location of the four study regions in Sweden, and the division of the studied sample plots into pine-, spruce- and birch-dominated and mixed forests.

vary between these regions. Within each region, the sample plots were further classified into pine-, spruce- or birch-dominated and mixed forests. A stand dominated by a species is defined as one in which pine, spruce or birch constitutes at least $70 \%$ of the basal area. Pine-dominated forests with small volumes are characteristically found in the north, whereas in the south stands are spruce-dominated and have high stem volumes. Mixed forests, which formed about one third of the sample plots, were not included in the calculations, since the division of volume between tree species within plots could not be taken into account in the calculations.

The Swedish NFI is organized as a systematic sample of temporary and permanent sample plots that annually covers the entire country [17]. In this design, an area-based ratio estimator is used to obtain the sampling error of the estimates. For this, special weights are used to combine sampling errors of estimates based on mean data from more than one year of inventory and to combine sampling errors from temporary and permanent sample plots.

\subsection{Application of biomass and volume equations}

The biomass for the tree fractions (stem wood, stem bark, branches and needles) was estimated by applying biomass equations [14] to the measured dimension (DBH) of sampled trees of the Swedish NFI [17]. Separate biomass functions were used for the tree species Scots pine (Pinus sylvestris), Norway spruce (Picea abies) and birch (Betula pen$d u l a$ and $B$. pubescens). These species constitute more than $90 \%$ of 
the standing stock [1]. The biomass equations for birch were applied to the remaining broad-leaved species such as aspen and alder. Only tree species and diameter at breast height (DBH) were used as independent variables in the biomass equations. To estimate the volume of the growing stock that was used in the calculation with BEFs, Näslund's volume equations [16] were applied to the treewise data of the NFI.

\subsection{Application of constant BEFs}

The BEFs were used to calculate the total aboveground biomass of trees based on the stem volume estimates, i.e.

$$
W=\mathrm{BEF} \times V
$$

where $W$ is the aboveground tree biomass (dry weight, $\mathrm{Mg}$ ), BEF the biomass expansion factor $\mathrm{Mg} \mathrm{m}^{-3}$ and $V$ the stem volume $\left(\mathrm{m}^{3}\right)$. Constant BEFs of 0.52 for Scots pine, 0.62 for Norway spruce and 0.64 for broad-leaved stands were applied in this study. These BEFs for aboveground biomass were derived from the National Inventory Report of Sweden [3]. Thus, they are consistent with the latest greenhouse gas reporting from Sweden, but they refer only to aboveground biomass.

\subsection{Application of age-dependent BEFs}

The tree species-specific age-dependent BEFs used in this study are based on those of Lehtonen et al. [11], where the BEF $B(t)$ is defined as follows,

$$
B(t)=a+b \times e^{\frac{-t}{100}},
$$

$B(t)$ being the BEF for the aboveground biomass $\left(\mathrm{Mg} \mathrm{m}^{-3}\right)$ and $\mathrm{t}$ the stand age (years), while $a$ and $b$ are parameters (Eq. (2), Tab. I). These age-dependent BEFs (Fig. 2) were used to convert growing stock to the aboveground biomass of trees according to Eq. (1), but now by ageclasses. The stand age-classes used were 11-20, 21-30, 31-40, 41$60,61-80,81-100,101-120,121-140$ and over 141 years.

\subsection{Different approaches to estimate biomass}

The aboveground biomass of trees was calculated in three different ways. In one, the biomass equations [14] were directly applied to treewise data of the NFI sample plots. In another, the stem volume equations were used to calculate the volume of the growing stock in the NFI sample plots, and the volume of the growing stock was converted to biomass estimates with the constant BEFs. In third method, the stem volumes were estimated as in the second method and the volume estimates were then converted to biomass by multiplying with the BEFs of the respective age-classes.

Table I. Parameter values for Eq. (2) according to study by Lehtonen et al. [11]. These BEF equations are used for Scots pine, Norway spruce and broad-leaved (for birch) stands to convert stem volume estimates to total aboveground biomass. BEF is $\mathrm{Mg} \mathrm{m}^{-3}$ and the independent variable stand age $(t)$ is in years.

\begin{tabular}{lccccc}
\hline Parameter & $a$ & $\begin{array}{c}\text { Standard } \\
\text { error }\end{array}$ & $b$ & $\begin{array}{c}\text { Standard } \\
\text { error }\end{array}$ & $\begin{array}{c}\text { Mean } \\
\text { of response }\end{array}$ \\
\hline Scots pine & 0.5436 & 0.0012 & 0.0193 & 0.0019 & 0.5548 \\
Norway spruce & 0.5734 & 0.0049 & 0.1272 & 0.0092 & 0.6358 \\
Broad-leaved & 0.5616 & 0.0041 & -0.0179 & 0.0056 & 0.5490 \\
\hline
\end{tabular}

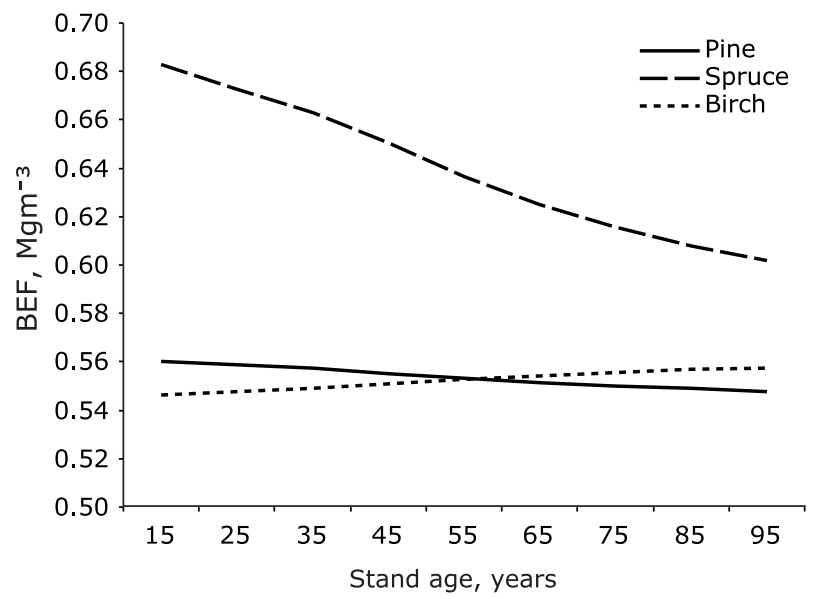

Figure 2. Age-dependent BEFs for Scots pine, Norway spruce and birch [11]. The estimates are calculated for the mean of the respective age-class, i.e. mean is $15,25,35,50,70,90,110,130$ or 150 years.

\subsection{Uncertainty for biomass estimates of standing stock}

First, we evaluated the reliability of the biomass estimates in terms of differences between the estimates obtained with alternative methods. The biomass estimates calculated with Marklund's allometric equations are considered to be the most realistic reference values for the biomass of trees in Sweden. In the present study, we showed the differences between the BEF-based estimates and the biomass estimate calculated with Marklund's equations according to age-classes and regions.

Second, we evaluated the differences between methods in terms of the relative standard errors (RSE) of the biomass estimates. Since the biomass equations were directly applied to treewise data of the NFI sample plots, the components of the errors accounted for are the sampling and biomass model errors (assumed to be small). In the BEFbased method, the sampling error in the volume estimate and error of the BEFs are accounted for. Here, the sampling error for the stem volume of permanent sample plots by age-classes was combined with the error of the BEFs [11] to obtain the RSE of the tree biomass stock in a given age-class using the following equation

$$
r_{\text {stock }, i}=\sqrt{r_{V, i}^{2}+r_{b e f, i}^{2}},
$$

where $r_{\text {stock,i }}$ is the relative standard error of the biomass stock in ageclass $i, r_{V, i} t$ the relative standard error of the estimate for total stem volume in age-class $i$, and $r_{b e f, i}$ is relative standard error of the BEF in age-class $i$.

Thereafter, the relative standard error of the overall biomass estimate of trees was calculated as

$r_{\text {tot }}=\frac{\sqrt{\left(r_{\text {stock }, 1} \times W_{1}\right)^{2}+\left(r_{\text {stock }, 2} \times W_{2}\right)^{2}+. .\left(r_{\text {stock }, n} \times W_{n}\right)^{2}}}{\left|W_{1}+W_{2}+. . W_{n}\right|}$,

where $r_{\text {tot }}$ is relative standard error of the total biomass (sum of all ageclasses), $W_{i}$ the biomass stock in age-class $i$ and $r_{\text {stock, } i}$ is the relative standard error of the biomass stock in age-class $i$. These error propagation equations are applicable to estimation of the overall uncertainty of a product of several quantities (Eq. (3)) and the overall uncertainty of the summed quantities (Eq. (4)) [5]. 
Table II. Relative standard errors (RSE) of biomass estimates and of the differences in biomass estimates according to dominant tree species in four different regions of Sweden. Calculations based on Marklund's biomass equations, nonage-dependent Swedish biomass expansion factors (BEF) and age-dependent BEFs.

\begin{tabular}{|c|c|c|c|c|c|c|c|c|c|c|}
\hline \multirow[t]{3}{*}{ Region } & \multirow[t]{3}{*}{ Stand type } & \multicolumn{2}{|c|}{$\begin{array}{c}\text { RSE for } \\
\text { biomass estimates }\end{array}$} & \multicolumn{3}{|c|}{ Biomass estimate of trees } & \multicolumn{4}{|c|}{$\begin{array}{l}\text { Difference between biomass estimates } \\
\text { (Marklund - BEF) }\end{array}$} \\
\hline & & \multirow{2}{*}{$\begin{array}{c}\text { Marklund } \\
\%\end{array}$} & \multirow{2}{*}{$\begin{array}{c}\text { Age-dep. } \\
\text { BEF } \\
\%\end{array}$} & \multirow{2}{*}{$\begin{array}{c}\text { Marklund } \\
\text { Mill. t }\end{array}$} & \multirow{2}{*}{$\begin{array}{c}\text { Nonage- dep. } \\
\text { BEF } \\
\text { Mill. t }\end{array}$} & \multirow{2}{*}{$\begin{array}{l}\text { Age-dep. } \\
\text { BEF } \\
\text { Mill. t }\end{array}$} & \multicolumn{2}{|c|}{$\begin{array}{c}\text { Marklund - } \\
\text { Nonage-dep. BEF }\end{array}$} & \multicolumn{2}{|c|}{$\begin{array}{c}\text { Marklund - } \\
\text { Age-dep. BEF }\end{array}$} \\
\hline & & & & & & & Mill. t & $\%$ & Mill. t & $\%$ \\
\hline \multirow[t]{4}{*}{ N Norrland } & Pine & 3.0 & 4.4 & 157.7 & 139.9 & 146.4 & 17.9 & 11.3 & 11.3 & 7.7 \\
\hline & Spruce & 6.5 & 6.7 & 85.8 & 75.1 & 75.3 & 10.7 & 12.4 & 10.5 & 14.0 \\
\hline & Birch & 8.3 & 11.0 & 13.9 & 12.6 & 10.7 & 1.3 & 9.5 & 3.2 & 29.5 \\
\hline & Mixed & & & $(102.6)$ & & & & & & \\
\hline \multirow[t]{4}{*}{ S Norrland } & Pine & 3.4 & 4.7 & 121.3 & 111.5 & 117.1 & 9.8 & 8.1 & 4.3 & 3.6 \\
\hline & Spruce & 3.5 & 5.2 & 177.4 & 169.2 & 133.3 & 8.2 & 4.6 & 44.1 & 3.7 \\
\hline & Birch & 10.2 & 12.9 & 8.2 & 7.6 & 6.5 & 0.6 & 7.5 & 1.7 & 26.4 \\
\hline & Mixed & & & $(125.2)$ & & & & & & \\
\hline \multirow[t]{4}{*}{ Svealand } & Pine & 2.7 & 4.2 & 141.9 & 129.5 & 120.6 & 12.4 & 8.8 & 21.3 & 4.6 \\
\hline & Spruce & 2.9 & 4.4 & 145.0 & 146.7 & 152.6 & -1.7 & -1.2 & -7.6 & -3.9 \\
\hline & Birch & 8.4 & 11.2 & 8.7 & 9.3 & 7.9 & -0.6 & -6.8 & 0.8 & 11.5 \\
\hline & Mixed & & & (136.3) & & & & & & \\
\hline \multirow[t]{4}{*}{ Götaland } & Pine & 2.9 & 4.4 & 102.8 & 91.8 & 96.3 & 11.0 & 10.7 & 6.6 & 6.4 \\
\hline & Spruce & 2.3 & 4.2 & 219.3 & 226.7 & 236.3 & -7.4 & -3.4 & -17.0 & -7.2 \\
\hline & Birch & 6.4 & 9.2 & 13.4 & 14.1 & 11.9 & -0.7 & -4.7 & 1.5 & 13.5 \\
\hline & Mixed & & & (162.5) & & & & & & \\
\hline Sweden & all * & & & 1195.6 & 1134.1 & 1115.0 & 61.6 & 5.1 & 80.7 & 6.7 \\
\hline
\end{tabular}

* Excluding mixed stands.

\section{RESULTS}

\subsection{Biomass comparisons}

At the national level, the highest estimate for the total aboveground biomass of trees was based on the treewise NFI data and biomass equations, totalling 1195.6 million $\mathrm{Mg}$ (Tab. II). The age-dependent BEFs gave the smallest estimate for the total biomass, being 1115.0 million $\mathrm{Mg}(6.7 \%$ smaller $)$, whereas the constant BEFs resulted in a biomass estimate of 1134.1 million $\mathrm{Mg}$.

The biomass estimates based on Marklund's equations [14] were an average of 4-30\% higher than the estimates calculated with age-dependent BEFs (Tab. II and Fig. 3). For pine, the differences in the estimates obtained with the various methods were generally smaller than for the other tree species (Fig. 4). The most divergent estimates for biomass were obtained for spruce in the Svealand and Götaland regions. In Svealand, the use of BEFs for Norway spruce in young stands resulted in lower, and in mature stands, higher biomass estimates than did use of the biomass equations. In Götaland, BEFs resulted in biomass estimate of mature Norway spruce stands $30 \%$ higher than that obtained with the Marklund's biomass equations. In comparison to Marklund's estimates, the BEF-based biomass estimate for birch was lower in the northern part of Sweden, while in the southern part the BEF-based biomass estimate for spruce was higher.
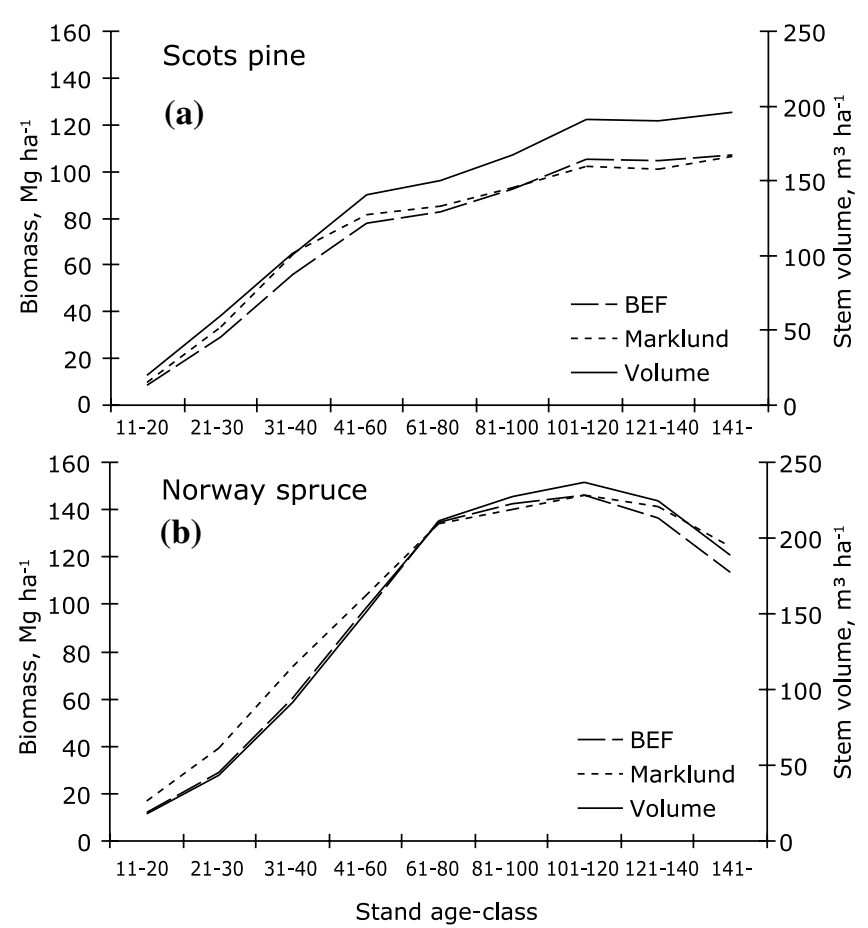

Figure 3. Total stem volume $\left(\mathrm{m}^{3} \mathrm{ha}^{-1}\right)$ and aboveground biomass ( $\mathrm{Mg} \mathrm{ha}^{-1}$ ) of (a) Scots pine and (b) Norway spruce according to stand age in Södra Norrland estimated with Marklund's allometric equations [14] and age-dependent biomass expansion factors [11]. 

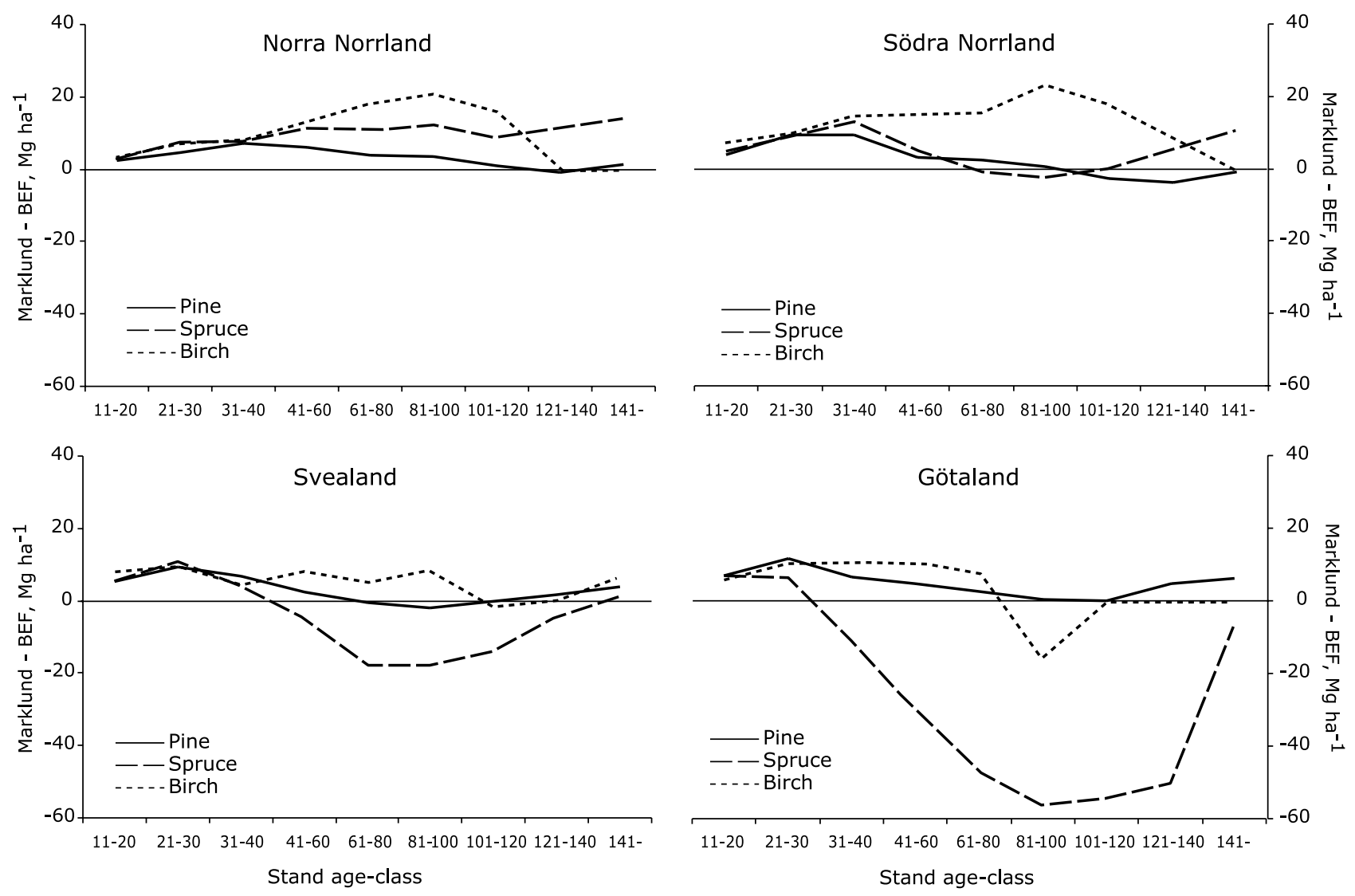

Figure 4. Difference between biomass estimates in the various age classes calculated with Marklund's equations, and those based on age-dependent BEFs in four regions in Sweden.

In absolute terms, the differences between biomass estimates appeared to peak in the intermediate forest age-classes, whereas in the youngest and oldest age-classes the estimates by the various methods agreed well (Fig. 4). However, as illustrated by an example for spruce, the differences in relative terms between the estimates obtained with various methods were also large among the youngest age-classes (Fig. 5).

\subsection{Error comparisons}

The errors associated with the biomass calculations at the tree level were compared with the errors produced by the calculations based on stand-level volume estimates and agedependent BEFs. In general, the relative standard errors (RSEs) for the BEF-based estimates were slightly larger than those based on Marklund's models, as shown in Södra Norrland (Fig. 6). The RSEs for all estimates ranged mostly from $10 \%$ to $20 \%$.

For both of the evaluated methods, the biomass estimates of the intermediate age-classes of forests were more accurate than those of the youngest and oldest age-classes. Of the tree species, the errors were smallest for pine and largest for birch. For birch, the dependency of precision on stand age was the most pronounced and the largest error was found in the oldest ageclasses, in contrast to spruce for which the errors were in the

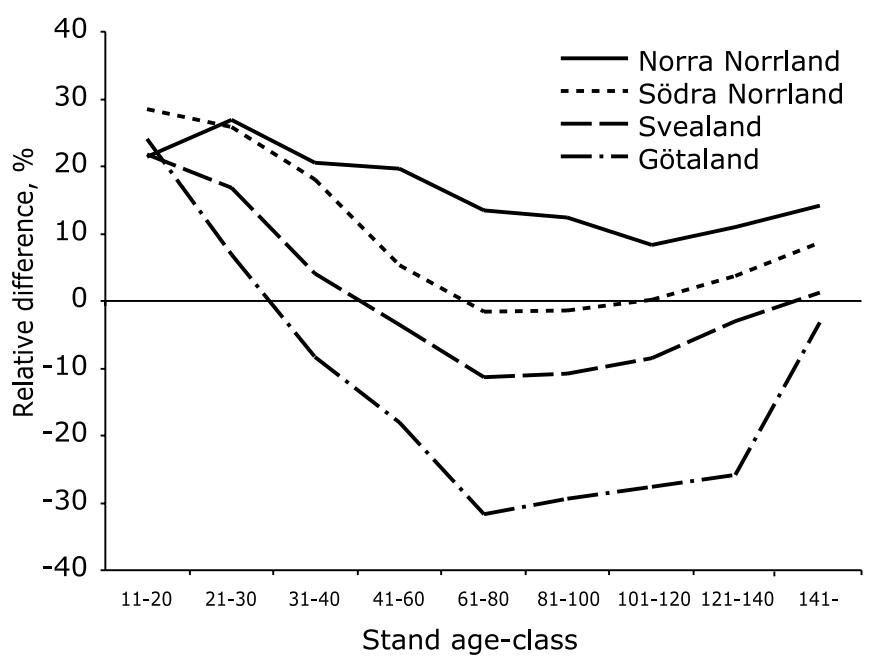

Figure 5. Relative difference in biomass estimates for spruce in the various regions, Marklund's estimate minus BEF-based estimate (\% of Marklund's estimate).

youngest age-classes. The errors for pine were not age-dependent. To summarize, the errors did not differ greatly among regions, but did among tree species. 

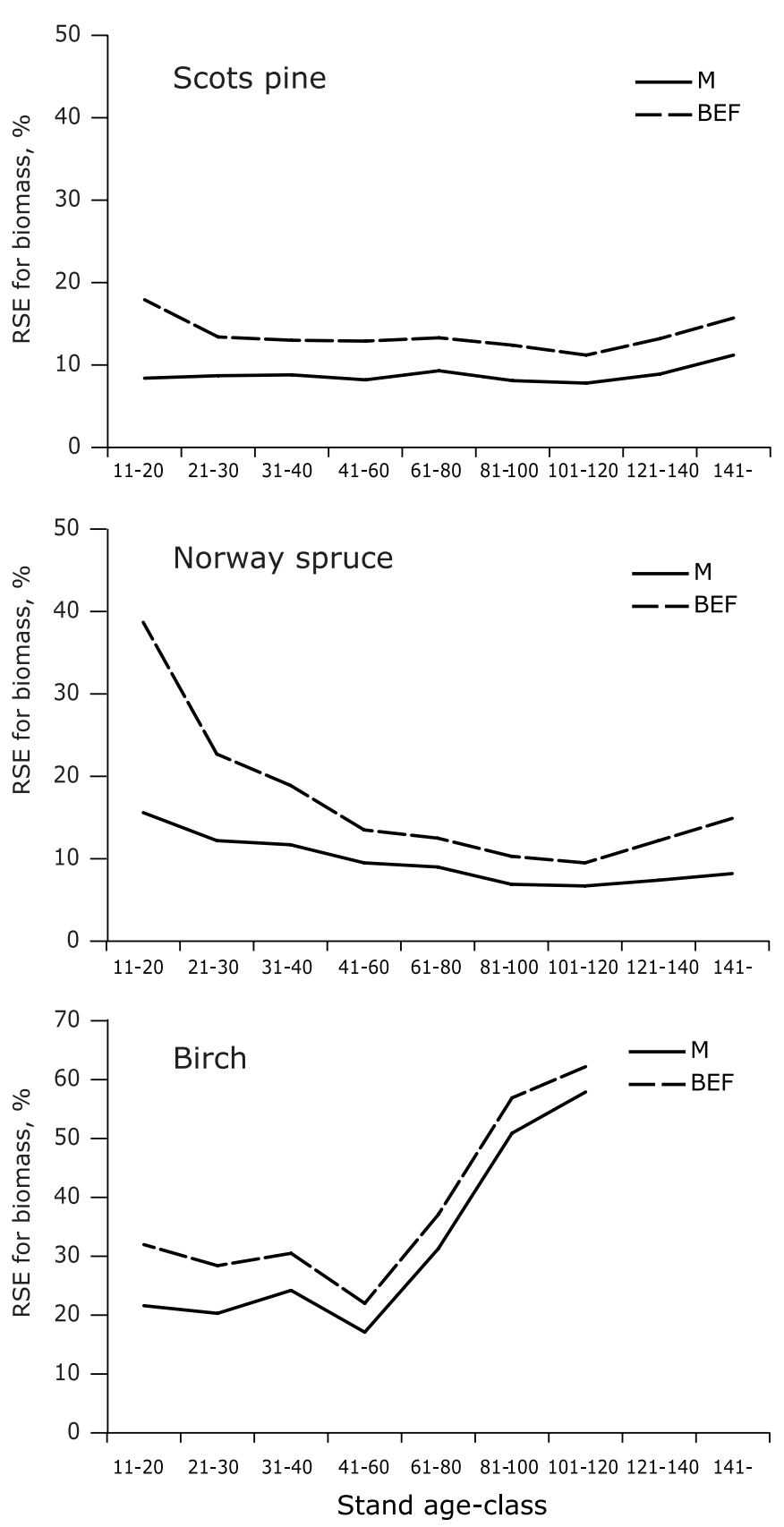

Figure 6. Estimated relative standard errors (RSEs) of the biomass estimates by dominant tree species in Södra Norrland. $M=$ error of the biomass estimate calculated with the Marklund's biomass equations (sampling error only accounted for) and $\mathrm{BEF}=$ error estimate including sampling error of the volume estimate and error of the BEF.

\section{DISCUSSION}

Regional and national biomass estimates have been and, according to IPCC good practice guidance, will continue to be calculated based on volume estimates with the aid of biomass expansion factors (BEFs) [5, 12]. However, the errors in national carbon assessment introduced by the applied BEFs may be large and unknown. Thus, the overall uncertainties resulting from the various calculation methods applicable to national assessment of the carbon stock of trees may differ considerably between countries. Our results show that the aboveground biomass stock of trees in Sweden estimated with the aid of the currently applied constant tree species-specific BEFs was $5 \%$ lower than the estimate obtained by applying Marklund's biomass equations directly to treewise data of the NFI. Thus, the currently applied constant BEFs resulted in relatively consistent biomass estimates with the other more detailed methods tested in this study. The BEFs previously applied in inventories performed in Sweden have, however, varied considerably from year to year [3, 4, 12, 21], with some resulting in biomass estimates as much as $20 \%$ higher than those obtained with the more detailed methods used here.

In general, the age-dependent BEFs [11] and use of biomass equations [14] resulted in relatively close biomass estimates. At the national level the positive and negative differences were balanced, and the overall difference in aboveground biomass between treewise estimates and age-dependent BEFs was surprisingly low, only $6.7 \%$ (excluding mixed stands).

The differences between biomass estimated with the agedependent BEFs and biomass equations were largest for Norway spruce stands in southern Sweden, where age-dependent BEFs of 60-100-year-old Norway spruce stands resulted in biomass estimates $30 \%$ higher than were obtained with the biomass equations. This indicates that these age-dependent BEFs cannot be applied to conditions under which stand development deviates from that encountered in the boreal forests of Finland. Under the more favourable conditions found in southern Sweden, the mean stem volumes of each age-class are evidently higher than those found under boreal conditions. Furthermore, the stem volumes of older Norway spruce stands in southern Sweden, which can exceed an average of $250 \mathrm{~m}^{3} \mathrm{ha}^{-1}$, fall outside the range of data used in formulation of these BEFs [11].

In Sweden, as well as in the other European countries, constant BEFs without quantitative uncertainty estimates have been applied in the reporting of carbon stock of trees to the UNFCCC [12]. Consequently, the overall error occurring with use of these constant BEFs cannot be assessed. The agedependent BEFs applied here were based on regionally representative sampling, account for variation in stand-level biomass allocation according to stand development and included error estimates [11]. The error estimates of the age-dependent BEFs applied in this study included both model and sampling errors, resulting in RSEs of the biomass estimate in the range of $4-13 \%$ at the regional level, depending on tree species. The errors in biomass estimates obtained with allometric equations ranged from $2 \%$ to $10 \%$, and only sampling errors were accounted for.

Both of the applied methods resulted in the highest degree of uncertainty of the biomass estimate in the young age-classes. The uncertainty of the biomass estimate calculated with the age-dependent BEFs was highest in the youngest age-classes due to the high degree of uncertainty of the BEFs in young stands. Since the age-dependent BEFs [11] were formulated based on the volume equations [9] and biomass equations [14], the model errors of both equations were included in the error of BEF. 
The uncertainties of the biomass estimates were, in general, highest for birch stands, intermediate for Norway spruce and lowest for Scots pine. The uncertainty in the biomass estimates of birch was high, since the number of birch stands was low in both the material used for formulation of the BEFs, and in the Swedish data on which the BEFs were applied, especially in the north.

The IPCC good practice guidance [5] recommends the use of BEFs and provides default values of BEFs for use in the Tier 1 method. Our results indicate that the applicability of the available BEFs needs to be carefully evaluated, especially for the possible presence of bias, before they can be used in the national inventories. Furthermore, it is evident that the time series of the inventory, i.e. the biomass estimates of the earlier inventories, needs to be recalculated when the BEFs are updated.

Acknowledgements: The study was funded by the Finnish Forest Research Institute, the Swedish University of Agriculture and Forestry and the CarboInvent consortium (project number EVK2-CT-200200157) of the European Commission under the 5th Framework Programme.

\section{REFERENCES}

[1] Anonymous, Forestry statistics 2002, Official Statistics of Sweden, Swedish University of Agricultural Sciences, Umeå, 2002, pp. 1107.

[2] Brown S., Measuring carbon in forests: current status and future challenges, Environ. Pollut. 116 (2002) 363-372.

[3] Feldhusen K., Hammarskjöld G., Mjureke D., Pettersson S., Sandberg T., Staaf H., Svensson U., Österberg K., Sweden's National Inventory Report 2004, Submitted under the United Nations Framework Convention on Climate Change, Swedish Environmental Protection Agency, 2004.

[4] Fink S., Feldhusen K., Hammarskjöld G., Pettersson S., Staaf H., Österberg K., Adolfsson R., Ivarsson A., Lidén M., Petersson H., Sweden's National Inventory Report 2003, Submitted under the United Nations Convention on Climate Change, Swedish Environmental Protection Agency, 2003.

[5] IPCC, Good practice guidance for land use, land-use change and forestry, IPCC National Greenhouse Gas Inventories Programme, 2004.

[6] Jenkins J.C., Chojnacky D.C., Heath L.S., Birdsey R., Nationalscale biomass estimators for United States tree species, For. Sci. 49 (2003) 12-35.

[7] Kauppi P.E., Mielikäinen K., Kuusela K., Biomass and carbon budget of European forests, 1971 to 1990, Science 256 (1992) 70-74.

[8] Kauppi P.E., Tomppo E., Ferm A., C and N storage in living trees within Finland since 1950s, Plant Soil 168-169 (1995) 633-638.
[9] Laasasenaho J., Taper curve and volume functions for pine, spruce and birch, Commun. Inst. For. Fenn. 108 (1982) 1-74.

[10] Laitat E., Karjalainen T., Loustau D., Lindner M., Towards an integrated scientific approach for carbon accounting in forestry, Biotechnol. Agron. Soc. Environ. 4 (2000) 241-251.

[11] Lehtonen A., Mäkipää R., Heikkinen J., Sievänen R., Liski J., Biomass expansion factors (BEF) for Scots pine, Norway spruce and birch according to stand age for boreal forests, For. Ecol. Manage. 188 (2004) 211-224

[12] Löwe H., Seufert G., Raes F., Comparison of methods used within member states for estimating $\mathrm{CO}_{2}$ emissions and sinks according to UNFCCC and EU monitoring mechanism: forest and other wooded land, Biotechnol. Agron. Soc. Environ. 4 (2000) 315-319.

[13] Marklund L.G., Biomass functions for Norway spruce (Picea abies (L.) Karst.) in Sweden, Swedish University of Agricultural Sciences, Dept. of Forest Survey, 1987, pp. 1-127.

[14] Marklund L.G., Biomassafunktioner för tall, gran och björk i Sverige, Sveriges lantbruksuniversitet, Rapporter-Skog 45 (1988) 1-73.

[15] Milne R., van Oijen M., A comparison of two modelling studies of environmental effects on forest carbon stocks across Europe, Ann. For. Sci. 62 (2005) 911-923.

[16] Näslund M., Funktioner och tabeller för kubering av stående träd. Tall, gran och björk i södra Sverige samt i hela landet., Meddelande från Statens Skogsförsöksanstalt 36 (1947) 1-81.

[17] Ranneby B., Cruse T., Hägglund B., Jonasson H., Swärd J., Design a new national forest survey for Sweden, Stud. For. Suec. 177 (1987) $1-29$.

[18] Schoene D., Assessing and reporting forest carbon stock changes for FRA, UNFCCC and Kyoto Protocol: a concerted effort? in: Luhtala A., Varjo J. (Eds.), Proceedings of FAO expert consultation on global forest resource assessment 2002, Metsäntutkimuslaitoksen tiedonantoja, 2002, pp. 290-297.

[19] Schroeder P., Brown S., Mo J., Birdsey R., Cieszewski C., Biomass estimation for temperate broadleaf forests of the United States using inventory data, For. Sci. 43 (1997) 424-434.

[20] Tomppo E., National forest inventory in Finland and its role in estimating the carbon balance of forests, Biotechnol. Agron. Soc. Environ. 4 (2000) 241-320.

[21] UN-ECE/FAO, Forest Resources of Europe, CIS, North America, Australia, Japan and New Zealand (industrialized temperate/boreal countries), UN-ECE/FAO Contribution to the Global Forest Resources Assessment 2000, Main Report, United Nations, New York and Geneva, 2000.

[22] Van Camp N., Vande Walle I., Mertens J., De Neve S., Samson R., Lust N., Lemeur R., Boeckx P., Lootens P., Beheydt D., Mestdagh I., Sleutel S., Verbeeck H., Van Cleemput O., Hofman G., Carlier L., Inventory-based carbon stock of Flemish forests: a comparison of European biomass expansion factors, Ann. For. Sci. 61 (2004) 677-682.

[23] Wirth C., Schumacher J., Schulze E.D., Generic biomass functions for Norway spruce in Central Europe - a meta-analysis approach towards prediction and uncertainty estimation, Tree Physiol. 24 (2004) 121-139. 